\title{
Job values among future business leaders: the impact of gender and social background
}

Published in Scandinavian Journal of Management 20(2004): 277-295

\section{Paul Gooderham,}

\section{Odd Nordhaug}

Norwegian School of Economics and Business Administration

Kristen Ringdal, Norwegian University of Science and Technology

Gunn Elisabeth Birkelund, University of Oslo

g.e.birkelund@sosiologi.uio.no

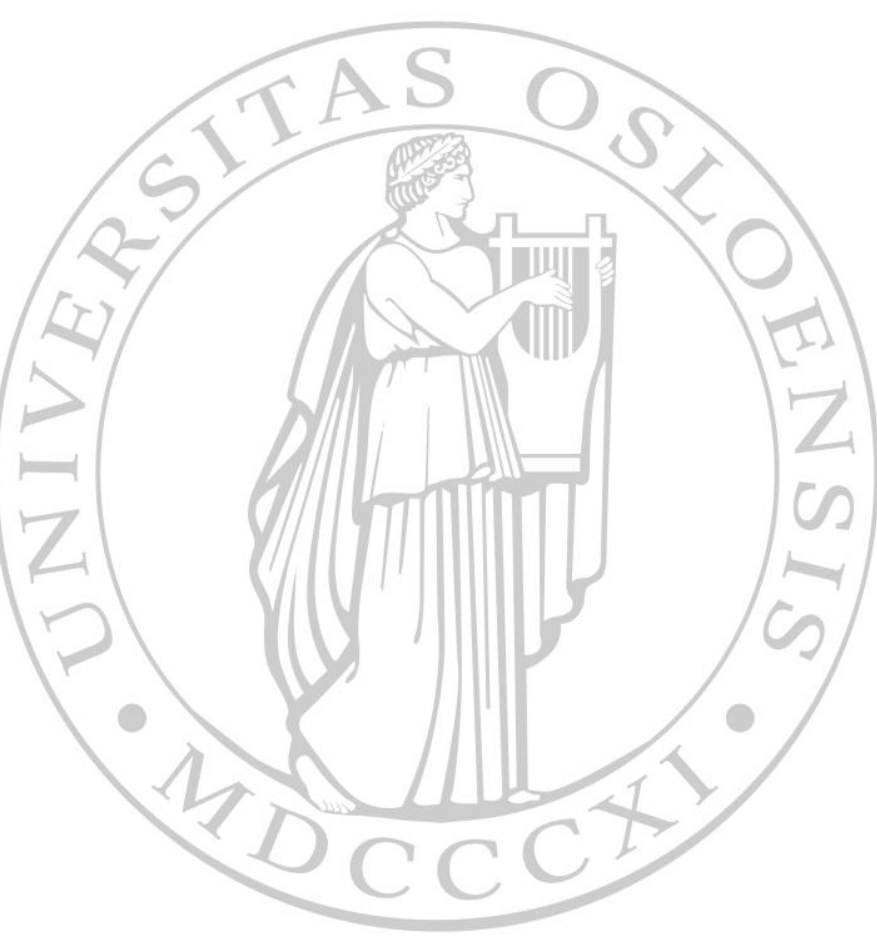

Department of Sociology and Human Geography University of Oslo

P.O.Box 1096 Blindern

N-0317 OSLO Norway

Telephone: $\quad+4722855257$

Fax: $\quad+4722855253$

Internet: http://www.iss.uio.no 


\title{
Job values among future business leaders: the impact of gender and social background
}

\author{
Paul Gooderham ${ }^{\mathrm{a}, *}$, Odd Nordhaug ${ }^{\mathrm{a}}$, Kristen Ringdal ${ }^{\mathrm{b}}$, \\ Gunn Elisabeth Birkelund ${ }^{\mathrm{c}}$ \\ ${ }^{a}$ Norwegian School of Economics and Business Administration, Helleveien 30, Bergen 5045, Norway \\ ${ }^{\mathrm{b}}$ Norwegian University of Science and Technology, Norway \\ ${ }^{\mathrm{c}}$ University of Oslo, Norway
}

Received 1 November 2002; accepted 1 January 2004

\begin{abstract}
The purpose of this paper is to investigate job-related values among Norwegian business school students. The study is based on a survey conducted in 1999 in the three leading national business schools among students who had completed almost 3 years of the 4-year degree program. We analyze the degree to which these values vary according to gender and social background. Previous research has indicated that business students are relatively materialistic and career-oriented, and that males are more so than females. However, in this paper, we find personal development to be the major motivational force among students of both genders. While the men are significantly more materialistic than the women, the difference is not very great. The analysis indicates that social background exerts no influence on job-related values. (C) 2004 Elsevier Ltd. All rights reserved.
\end{abstract}

Keywords: Job values; Job preferences; Business school students; Gender differences; Social differences

\section{Introduction}

In Scandinavia large private-sector businesses have traditionally recruited a substantial proportion of future fast-track managers from the national business schools offering the 4-year "siviløkonom" degree program. Entry into this program is highly competitive, requiring upper secondary education with exceptionally good grades. Many of Scandinavia's future business leaders can thus be found today

*Corresponding author. Tel.: +47-55-959-696; fax: +47-55-959-780.

E-mail address: paul.gooderham@nhh.no (P. Gooderham). 
amongst the students at these elite institutions. The initial purpose of this paper is to delineate the job-related values held by Norwegian business school students. We then seek to determine whether these values vary according to gender and social background.

Previous research has indicated that business school students in general hold materialistic job-related values (Cavanagh, 1984). However, the question can be raised as to whether these values are changing in response to processes of modernity, fuelled by rising standards of living and altered work processes that require and encourage new types of work motivation. Maccoby (1988) for example launched the term "self-developer", in seeking to pinpoint what he regards as the younger generation's more qualitatively oriented job demands. Self-developers are experience-seeking individuals who in many ways are ideally adapted to a work-life involving continuous change. Typical in this context are the demands for lifelong learning, for flexibility, networking, team-work and creative tasks.

Although qualitative work values are of fundamental importance here, this does not mean that self-developers disregard material rewards. What is different compared to earlier generations, though, is the relative ranking of such rewards. In this context it is relevant to refer to the thesis proposed by Inglehart (1993) whereby young people are characterized by post-material values, implying that material rewards are relegated to a secondary status.

Business students have traditionally embraced markedly materialistic values. Our analysis is intended to reveal whether the future career aims of today's students remain primarily materialistic or whether they are becoming non-materialistic. Furthermore, we intend to overcome a limitation in earlier research on job values and career plans (such as Maccoby's), by including gender and social background in the analysis.

\section{Gender and job-related values}

Previous research strongly indicates that we should expect to find marked gender differences in job-related values. Below we offer a brief review of some of these studies, starting with those that address the issue of value orientations.

A study conducted in the United States revealed that gender differences in fundamental value orientations among high school seniors, differences that showed little sign of decreasing during the period studied, 1977-1991 (Beutel \& Marini, 1995). These researchers developed three measures of value orientation

(1) compassion, which reflects concern and responsibility for the well-being of others; (2) materialism, which reflects emphasis on material benefit and competition; and (3) meaning, which reflects philosophical concern with finding purpose and meaning in life (Beutel \& Marini, 1995; p. 436).

Their study revealed substantial gender differences on all three measures. In particular, the young women were more concerned with the well-being of others, were less likely than the young men to accept materialism and competition, and 
finally were more likely than the young men to emphasize the importance of finding meaning in life. These gender differences were found in all social class subgroups.

Segal (1992) tested the assumption that particular types of studies attract people who possess the characteristics and values that are consistent with the value orientations of the profession concerned

Varying goals of professions underlie their supporting ideologies, or basic beliefs, about what constitutes 'the good life' and is expected to be reflected in the personal values and beliefs of those who make career decisions to join these professions (Segal 1992; p. 143).

Thus, in the case of highly competitive job environments, such as many business organizations represent, job-entry courses of study would recruit students with corresponding values, promoting and generating aggressiveness, flexibility and astuteness among the students. Segal compared business students with students of social work. Drawing on earlier research, she points out that social work has

...been assigned "feminine" characteristics such as nurturance, compassion, sympathy, helpfulness, warmth and sensitivity. On the other hand, business is ascribed the "masculine" characteristics of aggression, competition, independence, risk taking, dominance, and being analytic" (Segal 1992; p. 147).

However, Segal's own comparison of graduate social work students and graduate business students provided very little support for this conjecture either in terms of values or of personality. What she did note, though, was that there were marked gender differences within both groups: "regardless of choice of profession, females tend to respond like other females and males like other males" (Segal 1992; p. 143).

An investigation of work motivation among Swedish pupils at the upper secondary level that was conducted before and again after the economic recession at the beginning of the 1990s, also indicated clear gender differences. In particular, the boys emphasized monetary awards to a much greater extent than the girls (Gamberale, Bracken, \& Mardones, 1995). A comparison of attitudes to work among Polish and German students also revealed substantial gender differences. The males were much more inclined to look for work that was demanding in terms of time and personal commitment and that involved some degree of risk-taking (Maurer, Oszustowicz, \& Stocki, 1994).

Gender-based differences are also much in evidence in Norwegian research. Although the proportion of women undergoing higher education has increased greatly over the past 20 years, there remains a marked degree of gender segregation. This applies not only to the choice of degree subject, but also to the choice of career (Broch-Due, 1991; Nilsen, 1992). Thus, gender remains as potent a factor as it was in the early 1970s when Dokka and Büch-Holm (1974) studied the attitudes of business students to their courses, their work and their families. The findings of this study indicated that female business students were considerably more oriented towards personnel management as opposed to accountancy and finance. The authors concluded that personnel management was a traditionally female choice in that it is 
person-oriented, as opposed to accountancy and finance which are viewed as being more markedly bottom-line activities.

However, some of the studies referred to above are fairly old. It is thus important to note that gender ideology has changed over the period concerned. For more than a decade now, Norwegian researchers in the field of women's studies have been questioning the validity of regarding women as a homogenous group (Ve, 1977; Birkelund, 1992; Birkelund, Goodman, \& Rose, 1996; Ellingsæter, Noack, \& Rønsen, 1997). Likewise researchers within the field of men's studies have called for a more differentiated view of men (Morgan, 1992; Holter \& Aarseth, 1993; Hern, 1997; Oftung, 1997). In order to comprehend the impact of gender it is therefore necessary to allow for the variation between the values of men and women.

Moreover, it is also possible that gender differences, although still significant, have become less pronounced over time. Indeed an analysis of American students during the period 1976-1991 indicates that gender-based differences in job-related values among high school students are on the decrease (Marini, Pi-Ling Fan, Finley, \& Beutal, 1996). In one Norwegian study (Edvardsen, 1995), it was concluded that the differences in the values of Norwegian men and women between the ages of 16 and 18 had narrowed between 1980 and 1991. This conclusion was based primarily on the finding that because the 1991 male sample placed more emphasis on cooperation and social relations than their 1980 equivalents.

With these developments in mind let us look in more detail at modernity processes and their significance for changes in job-related values.

\section{Changing values}

Motivation theory can provide a useful route to an understanding of variations in job values. To put it simply motivation theory differentiates between two main work motives (Maslow, 1943, 1954; Herzberg, 1966; Alderfer 1969). The first involves instrumental or existential outcomes, such as income and rapid career progress. The second relates to expressive outcomes such as the possibility of personal growth and self-actualization. These two generic motives need not exclude one another; they can exist concurrently in one and the same individual (Alderfer, 1969). However, generally speaking there is a clear tendency for expressive outcomes to acquire greater importance with increases in levels of education and job status increase (Handy, 1981). Bearing this in mind, and considering that business school students are in the process of acquiring a high level of education and are normally offered good career prospects, it seems reasonable to suppose that they will not be exclusively instrumental in their orientations.

However, the motivation profiles among existing and future members of the workforce are not static. In a German study, Baegthe (1992) argues that western society is becoming increasingly infused with individualism as a consequence of modernity processes reinforced by the safety net provided by the welfare state. His research suggests that structural changes involving education and working-life have 
had a profound impact on the value orientations of young German adults. This is particularly the case in regard to their attitude to work

The most striking feature of the subjective relationship of the young people to their occupation is the energetic reference to their own emotionality and development of their personality and the openness with which they demand a chance to fulfill their need to express themselves in their work. At the same time they naturally do not forget the fact that they want to earn money for the work they do. As a result of the present, relatively good, and for the majority seemingly secure income level, this rudimentary demand on work can be ignored (Baegthe, 1992; p. 23).

Baegthe employs the concept of the self-developer (Maccoby, 1988) as a means of labeling this new motivation and attitude to work. A common aspect to both Baegthe and Maccoby's line of thought is that the evolution of these new forms of work motivation is rooted in processes of modernity. Driving these processes are factors such as global competition, liberalized trade regimes and a stream of new developments within IT and communication technologies. These factors have made it imperative to de-layer and flatten large bureaucratic industrial hierarchies in order to achieve the flexibility that these new structural conditions demand (Maccoby 1989; Løwendahl \& Nordhaug 1998; Nordhaug, 1999a). As Kanter (1991) phrased it, large organizations have to "learn to dance". Firms have to become "small and athletic" with communication flowing freely across the organization. Firms are increasingly offering their core employees stock options as a means of retaining and motivating them (Gulbrandsen, 1999; Nordhaug, 1999b).

These structural changes also have an impact on the selection of appropriate models of management. The new mode of production, which Maccoby refers to as "technoservice", necessitates the implementation of a series of complementary organizational forms including looser network-type organizations, team work, flatter structures, flexible work roles and less bureaucracy: "As organizations flatten out, there will be less opportunity for promotion. The traditional incentives of hierarchy, money status and power will be in short supply" (Maccoby, 1988; p. 20). Selfdevelopers are in many respects ideally suited for such a development. They represent a new form of work motivation involving greater emphasis on qualitative factors such as the lifelong learning and flexibility, greater individual latitude for decision making and the ability to work in teams. They have grown up in a rapidly changing world and are psychologically able to cope with the uncertainty that infuses markets and therefore organizations. According to Maccoby these characteristics have their genesis in changes in social norms that began in the 1960s in the United States. The younger generations were shaped by the general increase in the standard of living, by new political movements that attacked bureaucracy as an organizational model, by a greater emphasis on individual rights, by new technology and the growing participation of women in the labor force. This last factor is particularly salient: "the mass entry of women into the workplace signaled the end of the family with a sole male wage earner, and with it the traditional sex roles and the paternal model of managerial authority." (Maccoby, 1988; pp. 47, 48). 
Self-developers do not accept authoritarian forms of behavior. Authority is accepted only in so far as it is based on the possession of knowledge and competence. Self-developers are driven by a need to develop themselves, and they regard work primarily as a means of furthering this (Nordhaug, 1999c). They also wish to be able to determine the way they use their time, not least in order to be able to have a satisfying private life (Maccoby, 1988). Baethge's findings indicate that this last aspect, the balanced life, was particularly important to the women in his sample of German youth (Baethge, 1992).

Critics of the individualism of the younger generation have focused primarily on the normative implications of the constant pursuit of opportunities for selfrealization through rapid job changes. Lasch (1980) and Maccoby (1989) have argued that this generation is narcissistic, superficial, egotistical, and lacking in loyalty and a sense of duty. They have also argued that this generation has a tendency to underestimate the importance of reflection, experience and in-depth knowledge, of showing little consideration for others and of being indifferent to ethical issues.

A further source of possible variation in students' values is provided by postmaterialist theory. Inglehart (1990) posits that a gradual socio-cultural change is taking place characterized by a shift away from materialistic towards postmaterialistic values. This applies particularly to the younger generations, who have grown up in conditions of relative economic abundance and who are therefore prone to adopt values of the latter kind. This has implications for their attitudes to work and their job values

Prevailing motivations for work are changing, from an emphasis on maximizing income as the top priority, toward increasing emphasis on the quality of the work experience (Inglehart, 1993; p. 11).

If this thesis were correct, it would be reasonable to expect that even business students will emphasize values other than the purely material.

Research into Norwegian youth (Hellevik, 1993) indicates that they have responded to the material conditions in which they had grown up by being markedly more willing to take risks and to worry less about their economic security. At the same time, however, Hellevik found this did not imply indifference to material goods. On the contrary

For some of them this does not preclude a strong interest in the material aspects of existence in their search for immediate pleasure.(.) [Many] young men might more aptly be described as super-materialists (Hellevik, 1993; p. 224)

The question is whether we too will find "super-materialists" among business students and, if so, whether these students will be predominantly male as Hellevik has found.

For the purpose of the present study, we will expect students with materialistic job values to emphasize instrumental motivations for work, such as income and job security. Similarly, we will expect students with non-materialistic job values to 
emphasize expressive motivations for work, such as personal growth and selfactualization; i.e. self-development.

We can now formulate the following hypotheses.

(H1) Business students, regardless of sex, are expected to favor non-materialistic job values, (such as self-development) above materialistic values (such as income).

(H2) Male business students exhibit more materialistic job values than do female business students. That is, we expect male business students to be more motivated than female business students by, in particular, future income prospects.

\section{Social background and job values}

Despite a series of educational reforms and a large increase in the numbers of students continuing into higher education in Norway, there remains a strong association between social background and level of education. That is, the likelihood of an individual continuing into higher education is considerably greater if his/her parents possess higher education and middle-class occupations, than if their parents have the minimum level of education and working-class occupations (Knudsen, 1980; Lindbekk, 1993; Hansen \& Rogg, 1991; Hansen, 1995). The standard explanation for this association rests on the notion of class-based socialization occurring in relatively homogenous social environments. That is, working-class children are less likely to acquire the necessary value orientation for embarking on higher education. Added to this is the greater sense of uncertainty about the eventual benefits that may be derived from investing in higher education. It may be assumed that those who do continue into higher education will carry with them this baggage of values and expectations, such that we could expect to find an association between the parental background of business students and their job values. The question then is how do these individuals differ from their middle-class counterparts?

Boudon (1974) argues that children from middle-class backgrounds are encouraged from an early age to reproduce their social position at birth. As a consequence it would be reasonable to expect that students with such a background to be significantly more career-focused in terms of material rewards and social status than their counterparts from working-class backgrounds.

However, Bourdieu's theorizing upon the concept of cultural capital (Bourdieu, 1984) gives rise to an alternative possibility, namely that students from middle-class backgrounds might regard values of a purely materialistic type as vulgar, thereby demonstrating their "distinction" by emphasizing non-materialistic values such as personal development. According to this perspective, students from middle-class backgrounds would not be expected to display a strong career orientation, even if they did actually have such a leaning. On the other hand, students from workingclass backgrounds would have fewer qualms about openly acknowledging an instrumental career orientation. Inglehart's theory of post-materialist values 
(Inglehart, 1993) is broadly supportive of this position. Individuals who feel confident of being able to cope materially will be more inclined to emphasize expressive aspects of their future employment. Given that individuals from middleclass backgrounds tend to be self-assured, individuals from working-class backgrounds are likely to be the ones to entertain the more materialistic job values.

Thus, in regard to social background, we have two hypotheses.

(H3) Business students from working-class backgrounds exhibit more materialistic job values than students from middle-class backgrounds.

(H4) Business students from middle-class backgrounds exhibit more non-materialistic job values than students from working-class backgrounds.

\section{Data and methodology}

Our analysis is based on a standardized questionnaire and comprises 599 business students at the three major schools in Norway: the Norwegian School of Economics and Business Administration (NSEBA) in Bergen (344 respondents), the Norwegian School of Management (NSM) in Oslo (147 respondents), and the Bodø School of Business (BSB) in Bodø (99 respondents). Women account for about one-third of the students at NSM and NSEBA, while their share at BSB is slightly higher. The questionnaires were distributed, completed and collected during the plenary lectures that are compulsory for all third-year students at the respective institutions, and about 80 per cent of all 3-year students responded. The gender distribution of our samples mirrors exactly that of our population. In total, the data does not seem to suffer from any major problems as regards representativeness, unless the small proportion of students who did not attend the lectures were to differ extremely from the vast majority who did attend when it comes to job values. In view of the sample's exact replication of the population in terms of gender this seems highly unlikely.

The main component of our survey instrument comprises a battery of 11 items that map job values. In broad terms the items are derived from the work of Maslow, Herzberg and Alderfer, and thus range from pay and working conditions through to self-actualization and fulfillment needs. Their operationalization is relatively standardized in that they have been used by a number of other researchers working within this field (cf. Haire, Ghiselli, \& Porter, 1966; Cawsey, Reed, \& Reddon, 1982; England, 1986; Adigun and Stephenson, 1992). To gauge responses to each individual item we decided to use a five-point Likert scale, ranging from "not important at all" (1) to "very important" (5).

We define the following items as reflecting materialistic job values: high annual salary, physical working conditions, and rapid career progress. As reflecting nonmaterialistic job values we chose: interesting work tasks, good social relations, development of personal qualifications, variation in work tasks, agreement between job requirements and own abilities, high degree of job autonomy, job security, and flexible working hours. 
After presenting the descriptive statistics for each individual item, we perform a factor analysis. The resulting factors are then used as dependent variables in a multivariate analysis, conducted with the GLM program in SPSS 9.0 whereby the coefficients are estimated according to the regression technique.

Two main independent variables are used: gender and social background. A modified version of the Goldthorpe and Erikson class schema (Erikson and Goldthorpe, 1992) is used to operationalize social background.. Father's occupation is used as a proxy for class. The class variable consists of five categories: upper service-class, lower service-class, self-employed and manual workers.

In addition we also control for the effects of the age of the students and the business school they attend, i.e. NSM, NSEBA or BSB.

\section{Empirical analysis}

\subsection{Assessment of job values}

The students' mean responses to the 11 individual items are presented in Table 1, first for all students and then for male and female students separately. The items are ordered according to the means for the total sample. Interesting work and good social relations, together with varied work tasks and learning opportunities, i.e. nonmaterialistic job values, top the list for all students. In the case of these items the mean scores approach the maximum score of 5.0, indicating their absolute importance for business students. Opportunities for rapid career progress and flexible working arrangements are the least important of the job values for the sample as a whole. Note however, that the means for these last items also are relatively high, indicating that they do have some significance for business students.

We have hypothesized (H1) that male business students will exhibit more materialistic job values than female business students. Table 1 provides limited support only for this hypothesis. There are some differences in the rankings, particularly in regard to job security, but on the whole these are small. The correlation between the rankings for men and women is 0.89 . As regards differences in the means, there are nine statistically significant differences at the five percent level, but apart from job security the differences are modest. In the case of what is arguably the most potent indicator of economic returns, namely high wages, the difference is clearly not statistically significant.

\subsection{Factor analysis of job values}

As a means for simplifying the analysis and unearthing possible latent preference profiles (Eikeland, 1987; Hair, Anderson, \& Tatham, 1987; Berg, 1988; Nordhaug, 1989), we have chosen to conduct a factor analysis of the material included in Table 1. In factor analysis three measures are particularly important. Factor loadings indicate the correlations between the observed items and the latent factors. The eigenvalue is a measure of the variance that each factor accounts for in the set of 
Table 1

Descriptive statistics for job values by sex

\begin{tabular}{|c|c|c|c|c|c|c|c|c|c|}
\hline \multirow[t]{2}{*}{ Items } & \multicolumn{2}{|l|}{ All } & \multicolumn{2}{|l|}{ Male } & \multicolumn{2}{|c|}{ Female } & \multicolumn{3}{|c|}{ Gender differences ${ }^{\mathrm{a}}$} \\
\hline & Mean & Std. & Mean & Rank & Mean & Rank & $M-F$ & $t$ & Sig. \\
\hline $\begin{array}{l}\text { Interesting work } \\
\text { tasks }\end{array}$ & 4.81 & 0.41 & 4.77 & 1 & 4.88 & 1 & 0.11 & 3.65 & 0.000 \\
\hline $\begin{array}{l}\text { Good social } \\
\text { relations }\end{array}$ & 4.68 & 0.50 & 4.63 & 2 & 4.77 & 2 & 0.14 & 3.28 & 0.001 \\
\hline $\begin{array}{l}\text { Development of } \\
\text { personal } \\
\text { qualifications }\end{array}$ & 4.54 & 0.55 & 4.50 & 3.5 & 4.60 & 4 & 0.10 & 2.17 & 0.030 \\
\hline $\begin{array}{l}\text { Variation in work } \\
\text { tasks }\end{array}$ & 4.56 & 0.55 & 4.50 & 3.5 & 4.67 & 3 & 0.17 & 3.85 & 0.000 \\
\hline High annual salary & 4.16 & 0.63 & 4.18 & 5 & 4.12 & 7 & -0.06 & -1.31 & 0.192 \\
\hline $\begin{array}{l}\text { Good match } \\
\text { between job } \\
\text { requirements and } \\
\text { own abilities }\end{array}$ & 4.17 & 0.71 & 4.07 & 6 & 4.36 & 5 & 0.29 & 5.09 & 0.000 \\
\hline $\begin{array}{l}\text { High degree of job } \\
\text { autonomy }\end{array}$ & 4.01 & 0.74 & 3.97 & 7 & 4.09 & 8 & 0.12 & 1.90 & 0.058 \\
\hline $\begin{array}{l}\text { Physical working } \\
\text { conditions }\end{array}$ & 3.85 & 0.73 & 3.78 & 8 & 3.99 & 9 & 0.21 & 3.43 & 0.001 \\
\hline $\begin{array}{l}\text { Flexible working } \\
\text { hours }\end{array}$ & 3.76 & 0.83 & 3.70 & 9 & 3.85 & 10 & 0.15 & 2.25 & 0.025 \\
\hline $\begin{array}{l}\text { High degree of job } \\
\text { security }\end{array}$ & 3.83 & 0.90 & 3.65 & 10 & 4.14 & 6 & 0.49 & 6.97 & 0.000 \\
\hline $\begin{array}{l}\text { Rapid career } \\
\text { progress }\end{array}$ & 3.45 & 0.81 & 3.55 & 11 & 3.28 & 11 & -0.27 & -3.90 & 0.000 \\
\hline
\end{tabular}

Rank correlation (Spearman): 0.89 .

${ }^{a} M-F$, Male means minus female mean; $t$, Student's $t$-statistic; Sig., the probability level (two-sided) of the $t$-statistic.

items. Communality is a measure of the proportion of the variance that one item has in common with the other items in the factor analysis. The results of the factor analysis are presented in Table 2 .

The factor analysis returned four factors which together account for about $57 \%$ of the variance in the 11 items. The first factor embraces non-materialistic job values: interesting job tasks, varied job tasks and opportunities for personal competency development. We have labeled this factor self-development. The second factor involves a mix of mainly non-materialistic job values: job security, good social relations, physical conditions and a reasonable match of job demands and personal qualifications. This factor is labeled job security. The third factor comprises materialistic job values: opportunities for rapid career progress and high wages, and is labeled economic returns. Finally, the fourth factor is labeled flexibility, since it consists of flexible working arrangements and job autonomy, making it a third nonmaterialistic factor. 
Table 2

Factor analysis of job values, factor loadings, communalities and eigenvalues, $n=576$

\begin{tabular}{|c|c|c|c|c|c|}
\hline Items & F1 & $\mathrm{F} 2$ & F3 & $\mathrm{F} 4$ & $h^{2}$ \\
\hline Interesting work tasks & 0.750 & & & & 0.589 \\
\hline Variation in work tasks & 0.706 & & & & 0.581 \\
\hline Development of personal qualifications & 0.682 & & & & 0.491 \\
\hline High degree of job security & & 0.744 & & & 0.573 \\
\hline Good social relations & & 0.657 & & & 0.452 \\
\hline Physical working conditions & & 0.615 & & & 0.456 \\
\hline Good match between job requirements and own qualifications & & 0.555 & & & 0.421 \\
\hline Rapid career progress & & & 0.843 & & 0.728 \\
\hline High annual salary & & & 0.839 & & 0.723 \\
\hline Flexible working hours & & & & 0.833 & 0.710 \\
\hline High degree of job autonomy & 0.354 & & & 0.657 & 0.566 \\
\hline Eigenvalues (computed after rotation) & 1.755 & 1.710 & 1.493 & 1.333 & \\
\hline
\end{tabular}

Extraction Method: principal component analysis.

Rotation Method: varimax with Kaiser normalization.

F1, self-development; F2, job security; F3, economic returns; F4, flexibility, $h^{2}$, communalities.

\subsection{Multivariate analysis}

The next stage in our analysis is to examine the effect of gender and social background on the four factors, controlling for institutional differences and the age of the students. Descriptive statistics for the variables in the multivariate analysis are given in Table 3.

It may be noted that the distribution of the first and the fourth of the factors are virtually normal. Both the other two factors are slightly left-skewed.

In order to guard against Type I errors we have first executed a multivariate analysis of variance (MANOVA) using the GLM program in SPSS 9.0, in which the four preference dimensions are the dependent variables. Table 4 features three models. The first of these contains the main effects and all the two-way interactions among the four independent variables. The second contains the main effects only, while in the third model, the main effect of social class has been omitted.

The results in Table 4 clearly indicate that all interaction effects can be omitted from the first model. All the main effects except social class are statistically significant at the 0.05 level. The latter result is confirmed in model 2, and indicates that model 3, without the main effect of social class, is to be preferred for interpretation.

In Table 5, the regression parameter estimates from model 3 are reported for all four dependent variables. The last category of each of the independent factors is the reference category, i.e. male for Female, and $B S B$ for School. Thus, the coefficients for categorical variables are to be interpreted as differences in the means of the dependent variables (factors) between each individual category and the reference category. 
Table 3

Descriptive statistics for the variables in the multivariate analysis

\begin{tabular}{|c|c|c|c|c|}
\hline Continuous variables & Low & High & Mean & Std. \\
\hline F1: self-development & -3.68 & 1.64 & 0 & 1.0 \\
\hline F2: job security & -4.62 & 2.19 & 0 & 1.0 \\
\hline F3: economic returns & -3.70 & 2.17 & 0 & 1.0 \\
\hline F4: flexibility & -4.10 & 2.56 & 0 & 1.0 \\
\hline Age (in years) & 18 & 41 & 22.9 & 2.34 \\
\hline Categorical variables & Values & & Frequencies & $(\%)$ \\
\hline \multirow[t]{6}{*}{ FCLASS: Father's social class } & $0=$ Rest & & 104 & 17 \\
\hline & $1=\mathrm{I}$ upper service & & & \\
\hline & $2=$ II lower service & & 185 & 31 \\
\hline & $3=$ IV self-employed & & 54 & 9 \\
\hline & $4=\mathrm{V}-\mathrm{VII}$ workers ${ }^{\mathrm{a}}$ & & 82 & 14 \\
\hline & Sum & & 599 & 100 \\
\hline \multirow[t]{3}{*}{ Female } & $1=$ female & & 208 & 35 \\
\hline & $2=$ male $^{\mathrm{a}}$ & & 382 & 65 \\
\hline & Sum & & 590 & 100 \\
\hline \multirow[t]{4}{*}{ School } & $1=\mathrm{NSM}$ & & 151 & 25 \\
\hline & $2=$ NSEBA & & 348 & 58 \\
\hline & $3=\mathrm{BSB}^{\mathrm{a}}$ & & 100 & 17 \\
\hline & Sum & & 599 & 100 \\
\hline
\end{tabular}

${ }^{\mathrm{a}}$ Ref., reference category.

Gender has a significant impact on three of the four preference dimensions. Women score significantly higher than men on the self-development and job security factors, while they score lower than men on the materialistic factor. Although these differences are statistically significant, they are not substantially different. Differences in the range of $0.2-0.5$ in scales ranging from around $-4.5-+2.5$ are rather modest. As to the job flexibility factor, no statistically significant gender differences were observed.

The age of the students is only weakly related to job values. A negative relationship is observed between the job security factor and age, i.e. the older the students, the less emphasis there is on job security. There is a weak indication of the opposite relationship in the case of job flexibility factor $(b=0.03, t=1.635$, $p=0.103)$. When it comes to the factors self-development and economic returns, the relationships with age are not statistically significant at any conventional level.

With regard to the impact of place of study we observe that the NSEBA students score higher on the self-development factor than other students. The BSB students score higher on the job security factor than students at NSM or NSEBA. The results further indicate that the NSM students are those most inclined to give emphasis to 
Table 4

Multivariate tests (Wilks' lambda) of four value dimensions by sex, age, father's social class and school, $n=475$

\begin{tabular}{|c|c|c|c|c|c|c|}
\hline Effect & Wilks’ $\lambda$ & $F$ & Hyp. df & Error df & Sig. & Eta squared \\
\hline \multicolumn{7}{|c|}{ Model 1: main effects and all two-way interactions } \\
\hline Intercept & & 2.82 & 4 & 532 & 0.025 & 0.021 \\
\hline Father's social class & 0.979 & 0.71 & 16 & 1626 & 0.790 & 0.005 \\
\hline Female & 0.982 & 2.41 & 4 & 532 & 0.049 & 0.018 \\
\hline School & 0.984 & 1.08 & 8 & 1064 & 0.377 & 0.008 \\
\hline Father's social class $\times$ age & 0.980 & 0.67 & 16 & 1626 & 0.822 & 0.005 \\
\hline Female $\times$ age & 0.987 & 1.73 & 4 & 532 & 0.142 & 0.013 \\
\hline School $\times$ age & 0.987 & 0.86 & 8 & 1064 & 0.550 & 0.006 \\
\hline Father's social class $\times$ Female & 0.963 & 1.28 & 16 & 1626 & 0.202 & 0.010 \\
\hline Father's social class $\times$ School & 0.947 & 0.91 & 32 & 1964 & 0.608 & 0.014 \\
\hline Female $\times$ School & 0.988 & 0.78 & 8 & 1064 & 0.620 & 0.006 \\
\hline \multicolumn{7}{|c|}{ Design: Intercept + Father's class + Female + School + Father's social class $\times$ Age + Female $\times$ Age } \\
\hline \multicolumn{7}{|l|}{ Model 2: Main effects only } \\
\hline Intercept & 0.980 & 2.80 & 4 & 553 & 0.025 & 0.020 \\
\hline Father's social class & 0.975 & 0.87 & 16 & 1690 & 0.603 & 0.006 \\
\hline Female & 0.895 & 16.20 & 4 & 553 & 0.000 & 0.105 \\
\hline School & 0.919 & 6.00 & 8 & 1106 & 0.000 & 0.042 \\
\hline Age & 0.984 & 2.24 & 4 & 553 & 0.064 & 0.016 \\
\hline \multicolumn{7}{|c|}{ Design: Intercept + Father's social class + Female + School + Age } \\
\hline \multicolumn{7}{|l|}{ Model 3: Main effects-class } \\
\hline Intercept & 0.982 & 2.593 & 4 & 557 & 0.036 & 0.018 \\
\hline Female & 0.895 & 16.309 & 4 & 557 & 0.000 & 0.105 \\
\hline School & 0.913 & 6.502 & 8 & 1114 & 0.000 & 0.045 \\
\hline Age & 0.985 & 2.149 & 4 & 557 & 0.074 & 0.015 \\
\hline
\end{tabular}

the materialistic factor. As to the flexibility factor, there is a weak indication that the NSEBA students appreciate flexibility somewhat more than the NSM and BSB students $(b=0.203, t=1.704, p=0.089)$.

\section{Conclusions}

The analysis has indicated that the contention that Norwegian business students primarily exhibit materialistic job values is not correct. The ranking of means is topped by non-materialistic job values. However, the factor analysis did indicate that job values are multidimensional, and are more complex than a simple division between materialistic and non-materialistic values. At least four dimensions are 
Table 5

Parameter estimates from model 3 in Table 4, $n=475$

\begin{tabular}{|c|c|c|c|c|c|}
\hline Dependent variables & Parameter & $B$ & $\mathrm{Se}$ & $t$ & Sig. \\
\hline \multirow[t]{7}{*}{ F1: self-development } & Intercept & -0.759 & 0.464 & -1.634 & 0.103 \\
\hline & Age & 0.018 & 0.018 & 0.993 & 0.321 \\
\hline & Female $=1$ female & 0.293 & 0.086 & 3.399 & 0.001 \\
\hline & Female $=2$ male & Ref. & - & - & - \\
\hline & School = 1 NSM & 0.070 & 0.136 & 0.515 & 0.607 \\
\hline & School $=2$ NSEBA & 0.387 & 0.116 & 3.327 & 0.001 \\
\hline & $\begin{array}{l}\text { School }=3 \text { BSB } \\
R^{2}\end{array}$ & Ref. & - & - & - \\
\hline \multirow[t]{7}{*}{ F2: job security } & Intercept & 1.015 & 0.455 & 2.231 & 0.026 \\
\hline & Age & -0.040 & 0.018 & -2.185 & 0.029 \\
\hline & Female $=1$ female & 0.541 & 0.084 & 6.406 & 0.000 \\
\hline & Female $=2$ male & Ref. & - & - & - \\
\hline & School = 1 NSM & -0.338 & 0.133 & -2.542 & 0.011 \\
\hline & School $=2$ NSEBA & -0.370 & 0.114 & -3.249 & 0.001 \\
\hline & $\begin{array}{l}\text { School }=3 \text { BSB } \\
R^{2}\end{array}$ & Ref. & - & 一 & - \\
\hline \multirow[t]{8}{*}{ F3: economic returns } & Intercept & 0.204 & 0.469 & 0.436 & 0.663 \\
\hline & Age & -0.007 & 0.019 & -0.382 & 0.703 \\
\hline & Female $=1$ female & -0.240 & 0.087 & -2.762 & 0.006 \\
\hline & Female $=2$ male & Ref. & - & - & - \\
\hline & School=1 NSM & 0.344 & 0.137 & 2.514 & 0.012 \\
\hline & School $=2$ NSEBA & -0.076 & 0.117 & -0.646 & 0.519 \\
\hline & School $=3$ BSB & Ref. & - & - & - \\
\hline & $R^{2}$ & & & & \\
\hline \multirow[t]{7}{*}{ F4: flexibility } & Intercept & -0.879 & 0.477 & -1.845 & 0.066 \\
\hline & Age & 0.031 & 0.019 & 1.635 & 0.103 \\
\hline & Female $=1$ female & 0.135 & 0.088 & 1.526 & 0.128 \\
\hline & Female $=2$ male & Ref. & - & - & - \\
\hline & School=1 NSM & 0.034 & 0.139 & 0.245 & 0.807 \\
\hline & School $=2$ NSEBA & 0.203 & 0.119 & 1.704 & 0.089 \\
\hline & $\begin{array}{l}\text { School = 3 BSB } \\
R^{2}\end{array}$ & Ref. & - & - & - \\
\hline
\end{tabular}

$B$, metric regression coefficient; Se, standard error of $B$; $t$, student's $t$; Sig., the probability value of $t$.

necessary to describe the job values of the students in our study, where we found three factors comprising non-materialistic job values and one factor comprising materialistic values.

Our results support the hypothesis on gender differences in job values: female students are more likely than male students to favor non-materialistic job values, but the observed gender differences are rather small. Neither of the two opposing hypotheses on the relationship of social class and job values seems to apply to business students, as the analysis yielded statistically non-significant results only. 
Age is related to two of the four dimensions of job values. The older the students, the more emphasis there is on self-development and the less on job security.

Some differences among the schools were also observed. The NSEBA students gave higher priority to self-development than other students, the NSM students were the most materialistic, and the BSB students seem to value job security more highly than the NSM or NSEBA students.

Our study has shown that gender has far less consequence impact for job values of business students than previous research has suggested. The majority of Norwegian business school students, irrespective of gender, tend to fit Maccoby's self-developer concept.

However, this does not mean that these students are indifferent to material rewards or security: the first of these is more pronounced among men and the second among the women.

The fact that social background has no impact may be explained by two competing factors. First, it is quite possible that the students already shared a common set of values prior to attending business school. Another possibility is that social differences in values are replaced by a common set of values acquired at the business schools. Future research should develop a design that makes it possible to assess the relative impact of these two factors.

One interesting theoretical possibility raised by our research is that gender as a category for explaining variations in work-related values may be losing ground, at least in Scandinavia with its history of comprehensive and pervasive sex equality policies. In turn we might wonder whether, as Durkheim (1897/1951) predicted, that a person's profession is becoming the major source of identity as the division of labor in society becomes increasingly specialized and, therefore, more fragmented. Durkheim argues that occupational groups are particularly well suited "to bear social ideas and sentiments" (1951; p. 378). Might it be that female business students have more in common with their male counterparts than they have with, for example, female students of social work or nursing? One indication that this may indeed be the case is to be found in a recent Norwegian study, where comparisons on these lines are made (Bang, 2002).

On a more practical note: as regards attracting, motivating and retaining management recruits our study, has implications for the design of the architecture of the human resource management in work organizations. The findings indicate that almost regardless of gender, extrinsic materialistic job values such as high annual salary and rapid career progress are less strong motivators than intrinsic values such as interesting and varied work tasks and the quality of the social environment. In short, the challenge is to create work environments that not only provide individuals with personal growth opportunities, but that are also structured to allow for the fulfillment of social needs. We suggest that it is precisely the resolution of this paradox - on the one hand the need for self-development, and on the other the need for positive social relations - that represents the core task for human resource managers in the age of the knowledge worker. However, we would further suggest that this issue cannot be resolved by management alone. Management recruits should also receive, as part of their business education, substantial training in how to 
contribute to the resolution of this paradox. This implies a much greater element of team-based studies and problem-solving than is the current norm in Scandinavian schools and universities, where individual achievement and its evaluation still remain the predominant focus.

Finally, one aspect of gender also calls for comment. Male and female management recruits clearly differ in relation to their preferences regarding job security. For women this clearly is of some significance. It would seem that while both sexes are seeking jobs that provide them with growth opportunities and good social relations, females are also conscious that their roles in the workplace must be balanced against their current or prospective family roles. For many women in working-life a certain amount of job security is certainly a precondition for achieving this balance. In this context gender remains a potent force. Firms with a commitment to recruiting more women into managerial positions must be particularly sensitive on this point if they are to succeed in their aim.

\section{Appendix A. Relevant extracts from the questionnaire}

Below we present the exact wording of the items in the questionnaires referred to in this article.

\section{A.1. Criteria for choosing job and first employer}

Below we have listed various conditions related to jobs and workplaces. Please indicate how important these are to you when choosing job/employer after having completed your business studies. Please encircle the most appropriate number, ranking from very important (5) to not important at all (1).

Characteristics of job/position/workplace

\begin{tabular}{lllllc} 
& \multicolumn{2}{c}{ Not important at all } & \multicolumn{2}{c}{ Very important } \\
Interesting work tasks & 1 & 2 & 3 & 4 & 5 \\
Good social relations & 1 & 2 & 3 & 4 & 5 \\
$\begin{array}{l}\text { Good opportunities to develop } \\
\text { personal qualifications }\end{array}$ & 2 & 3 & 4 & 5 \\
$\begin{array}{l}\text { Variation in work tasks } \\
\text { High annual salary }\end{array}$ & 1 & 2 & 3 & 4 & 5 \\
$\begin{array}{l}\text { Good match between job } \\
\text { requirements and own abilities }\end{array}$ & 1 & 2 & 3 & 4 & 5 \\
$\begin{array}{l}\text { High degree of job autonomy } \\
\text { Good physical working }\end{array}$ & 1 & 2 & 3 & 4 & 5 \\
conditions & 1 & 2 & 3 & 4 & 5 \\
$\begin{array}{l}\text { Flexible working hours } \\
\text { High degree of job security }\end{array}$ & 1 & 2 & 3 & 4 & 5 \\
Rapid career progress & 1 & 2 & 3 & 4 & 5 \\
\end{tabular}




\section{A.2. Background information}

Sex:

\section{Your father's education:}

9 years

10-12 years

13-15 years

More than 15 years
Female

2

Your mother's education:

$\begin{array}{ll}9 \text { years } & 1 \\ 10-12 \text { years } & 2 \\ 13-15 \text { years } & 3 \\ \text { More than } 15 \text { years } & 4\end{array}$

\section{References}

Adigun, I. O., \& Stephenson, G. M. (1992). Sources of job motivation and satisfaction among British and Nigerian employees. Journal of Social Psychology, 132(3), 369-376.

Alderfer, C. P. (1969). An empirical test of a new theory of human needs. Organizational Behavior and Human Performance (bd. 4), s.142-s.175.

Baethge, M. (1992). Changes in work and education as constituting factors of social identity. Theoretical and political implications. In T. Halvorsen \& O. J. Olsen (Eds.), Det kvalifiserte samfunn? Oslo: Ad Notam Gyldendal.

Bang, K. (2002). Materialistiske egoister og idealistiske hjelpere? Om studium, kjønn, klasse og verdier: En undersøkelse av siviløkonomstudenter og sosionomstudenter (Materialistic egocentrics and idealistic helpers? Type of education, gender, class and values). Unpublished Masters thesis, Department of Sociology and Social Geography, University of Oslo, Oslo.

Berg, L. (1988). Studiemotivasjon. Oslo: NAVFs utredningsinstitutt.

Beutel, A. M., \& Marini, M. M. (1995). Gender and values. American Sociological Review, 60, 436-448.

Birkelund, G. E. (1992). Stratification and segregation. Acta Sociologica, 35, 47-62.

Birkelund, G. E., Goodman, L. A., \& Rose, D. (1996). The latent structure of job characteristics of men and women. American Journal of Sociology, 102, 80-113.

Boudon, R. (1974). Education, Opportunity and Social Inequality. New York: Wiley.

Bourdieu, P. (1984). Distinction. Cambridge, MA: Harvard University Press.

Broch-Due, A.-K. (1991). Kjønn forstått som katergori, relasjon og prosess. Ungdoms syn på fremtidig yrkesaktivtiet og omsorgsoppgaver. In R. Haukaa (Ed.), Nye kvinner, nye menn. Oslo: Ad Notam.

Cavanagh, G. F. (1984). American business values (2nd ed.). Englewood Cliffs, NJ: Prentice-Hall.

Cawsey, T., Reed, P., \& Reddon, J. (1982). Human needs and job satisfaction: A multidimensional approach. Human Relations, 35(9), 703-715.

Dokka, E., \& Büch-Holm, M. (1974). Kvinnelige NSEBA-studenters holdning til studiet, arbeid og familieliv. En innstillingsundersøkelse blant kvinner opptatt ved NSEBA i perioden 1970-73. Norwegian School of Economics and Business Administration, Bergen. 
Durkheim, E. (1897/1951). Suicide: a study in sociology (original title, Le suicide: étude de sociologie). New York: Free Press.

Edvardsen, R. (1995). Yrkesvalgmotiver. Oslo: Utredningsinstitutt for forskning og høyere utdanning.

Eikeland, J. (1987). Universitetet i Bergen som utdanningsinstitusjon. University of Bergen, Bergen.

Ellingsæter, A. L., Noack, T., \& Rønsen, M. (1997). Sosial ulikhet blant kvinner: Polarisering, utjevning eller status quo? Tidsskrift for samfunnsforskning, 38(1), 33-69.

England, G. W. (1986). National work meanings and patterns: Constraints on management action. European Management Journal, 4(3), 76-84.

Erikson, R., \& Goldthorpe, J. H. (1992). The Constant Flux. Oxford: Clarendon Press.

Gamberale, F., Bracken, R., \& Mardones, S. (1995). Work motivation among high school students before and during the economic recession in the Swedish labour market. Scandinavian Journal of Psychology, 36(4), 287-294.

Gulbrandsen, T. (1999). Eiere og kolleger. Medeierskap i norsk arbeidsliv.. Oslo: Institute of Social Science.

Hair, J. F., Anderson, R. E., \& Tatham, R. L. (1987). Multivariate data analysis. New York: Macmillan.

Haire, M., Ghiselli, E. E., \& Porter, L. W. (1966). Managerial thinking: An international study. New York: Wiley.

Handy, C. (1981). Understanding organizations. Harmondsworth: Penguin Books.

Hansen, M. N. (1995). Class and inequality in Norway. Oslo: Institute of Social Science.

Hansen, M. N., \& Rogg, E. (1991). Høyere utdanning i Norge Rekruttering, finansiering og omfordeling. Tidsskrift for samfunnsforskning, 32(4), 387-416.

Hellevik, O. (1993). Postmaterialism as a dimension of cultural change. International Journal of Public Opinion Research, 5(3), 211-233.

Hern, J. (1997). Hva innebærer kritiske studier av menn? Kvinneforskning, 1-97.

Herzberg, F. (1966). Work and the nature of man. Cleveland: World Publishing.

Holter, Ø. G., \& Aarseth, H. (1993). Menns livssammenheng. Oslo: Ad Notam.

Inglehart, R. (1990). Culture shift in advanced industrial society. Princeton, NJ: Princeton University Press.

Inglehart, R. (1993). Modernization and postmodernization: The changing relationship between economic development, cultural change and political change. Paper presented at The Conference on Changing Social and Political Values, Complutense University, Madrid, September 27-October 1, 1993.

Kanter, R. M. (1991). Når de store elefantene danser. 90-årenes utfordringer innenfor strategi, ledelse og personlig karriere. Oslo: Cappelen.

Knudsen, K. (1980). Ulikhet i grunnskolen. Bergen: Norwegian University Press.

Lasch, C. (1980). The culture of narcissism. London: Abacus.

Lindbekk, T. (1993). School reforms in Norway and Sweden, and the redistribution of Educational Attainments. Scandinavian Journal of Educational Research, 37(2), 129-149.

Løwendahl, B. R., \& Nordhaug, O. (1998). Kompetanserevolusjon og frihetsledelse. In O. Nordhaug (Ed.), Kompetansepolitikk 2000+. Oslo: Tano Aschehoug.

Maccoby, M. (1988). Why work? Leading the new generation. New York: Simon and Schuster.

Marini, M., Pi-Ling Fan, M., Finley, E., \& Beutel, A. M. (1996). Gender and job values. Sociology of Education, 69(1), 49-65.

Maslow, A. H. (1943). A theory of human motivation. Psychological Review, 370-396.

Maslow, A. H. (1954). Motivation and personality. New York: Harper \& Row.

Maurer, A., Oszustowicz, B., \& Stocki, R. (1994). Gender and attitudes toward work. International Journal for the Advancement of Counceling, 17(1), 35-46.

Morgan, D. (1992). Discovering men. London: Routledge.

Nilsen, A. (1992). Women's ways of caring. A life-course approach to the occupational careers of three cohorts of engineers and teachers. Bergen: Department of Sociology, University of Bergen.

Nordhaug, O. (1999a). Fra byråkrati til ludokrati. In O. Nordhaug (Ed.), Ledelse 2000+. Trender og utfordringer. Oslo: Cappelen Akademisk Forlag.

Nordhaug, O. (1999b). Morgendagens ledere: Hvem er de? In O. Nordhaug (Ed.), Ledelse 2000+. Trender og utfordringer. Oslo: Cappelen Akademisk Forlag.

Nordhaug, O. (1999c). Epilog ved millenniumskiftet. In O. Nordhaug (Ed.), Ledelse 2000+. Trender og utfordringer. Oslo: Cappelen Akademisk Forlag. 
Nordhaug, O. (1989,). Reward functions of personnel training. Human Relations, 42, 373-388.

Oftung, K. (1997). Mannsforskning. Kvinneforskning, 3-4-97.

Segal, U. A. (1992). Values, personality and career choice. The Journal of Applied Social Sciences, 16(1), $143-159$.

Ve, H. (1977). Sosialisering, kjønn og klasse. In T. Berg (Ed.), I kvinners bilde. Bidrag til en kvinnesosiologi. Oslo: Pax. 